\title{
The Algerian bank between eco-regulations and development of cus- tomer loyalty
}

\section{Zerigui Khadidja}

$\mathrm{PhD}$ student and teacher-researcher, Department of Economics, University of Oran 2 Mohamed Ben Ahmed, Algeria.

\section{Boulenouar Bachir}

Lecturer "A", Department of Economics, University of Oran 2 Mohamed Ben Ahmed, Algeria.

\begin{abstract}
The object of the present paper is to present the Algerian banking system. In this perspective, we wish in the first place to present the composition of the Algerian banking system and the succession of the creation of six national banks, then the setting-up of the foreign banks (private banks) within this system and who create a new dynamism of the banking competition. Given that the second part of the document is intended for a part of our empirical study, which amounts in development of customer loyalty and which represents the pit of the bank, the latter is characterized by the requirement and the influence of the customs and of the traditions of the society. We are going to present a part of the statistics of our study to demonstrate on which base the chosen client his bank enters public and private and why the public bank is favored by customers' large number.
\end{abstract}

Keywords: banking System, economy, banks, competition, customer (client), marketing, strategy. JEL Classification: G00, G19.

(C) The Authors, 2018. This article is published with open access at Sumy State University.

\section{Introduction}

In an economy known by his very difficult environment, the company has to survive in turbulences and permanent changes. The first conception of the environmental turbulence was made in the 60 s with Emery and Trist $^{1}$, afterward popularized by Drucker ${ }^{2}$ which qualified by a big undid. Ansoff ${ }^{3}$ insisted on the necessity of a planning to minimize the damages and better manage these turbulences.

In this respect, the company has to stand out and distance itself from others, to persist in the competition, then it sets up actions to renew its range of products, to place it better, to promote its sales, to improve or to maintain its brand image in mind of the consumer.

The service sector does not escape from this situation and has to know the same changes; in spite of the traditional banking economy is essentially interested in the links between change and credit at the macroeconomic level and in particular at the transmission mechanisms of the monetary policy led by the central bank. But, from the beginning of the eighties, the modern approach, adopted a more microeconomic point of view, by studying in a detailed way the behavior of banks individually confronted with the evolution of their competitive and statutory environment ${ }^{4}$. It explains the big changes which knows the banking sector, because banks are going to have to be engaged in a world competition seen the multinationalization of a large number of the latter, because play an essential role for the smooth running of the global economy. They also constitute an important component in the service sector, which knew these last years of the important evolutions, thanks to these banks who settled down almost in all the countries of the world. These banks became rival in the local financial markets; while any banks try to survive and to guarantee her place in the market in the face of compete.

Algeria and since is independence, is a member of countries which modified substantially their financial structure by aiming at a bigger integration in the global economy, at the time of the financial globalization and of the universalization of markets. This is why Algeria propagated important structural commitments to establish

\footnotetext{
${ }^{1}$ Emery and Trist «The Causal texture of oraganizattinal environement» Washington D.C, USA, Agust 1963.

${ }^{2}$ Peter F Drucker «The age of discontinuity : guidelines to our changing society» Copyrighted Material edition, New York, 1992.

${ }^{3}$ Igor Ansoff «Matrix, environment, and growth-an interactive triangle» 1993.

4 Emannuel GABILLON, professor in economic sciences at the university of Bordeaux-IV-Montesquieu and Jean ROCHET, professor at the university of Toulouse-I: «économie de la banque», article published in the dictionnairy of economiy, universitary encyclopaedia 2007.
} 
the bases of a strong and long-lasting economic growth. The latter, have for main purpose the strengthening of the macroeconomic stability, the continuous improvement of the environment of the business and the commercial opening ${ }^{1}$.

Since 1990, two big waves of reforms one given rhythm the Algerian banking system. The first wave joined the global frame of the reforms of the economic system aiming at the passage of the economy state-controlled and planned in the market economy, to adapt sectors to the new requirements of the financing and the regulation of the economy ${ }^{2}$.

Just after these reforms, about ten private and foreign banks penetrated into the Algerian financial market. While the competition took its shape, managed by the regulations and the legislations of the Algerian state. Besides, the banking system knew a development and a multiplication of number of installed banks, twenty banks between national and multinational practice and contribute in the tertiary sector. These banks, to face the competition and the contribution in the financial market there, they appeal more and more to the techniques of the banking marketing, this is well translated in our everyday life by the successive appearance of new ranges of services and facilitations of access to the bank. Each, tries to offer to these customers the best products and the easiest operations, she also has to throw novelties to find her place in the financial market in front of a vast competition.

The strategic approach is essential, because the loyalty of the consumer must be envisaged as a strategic objective $^{3}$. This approach must be present in all the credit institutions, which are faced in the globalization of markets and a universe competitive with the renewed outlines, try to mark out the ways of their future. This initiative is realized by the highest hierarchical levels of the bank ${ }^{4}$. Besides, the application of the marketing strategy allows the bank to save its ways, the speed with regard to the competition and the adaptation to the environment which is complex, varying and very changeable. This is why we chose to study the Algerian banking system then the application of marketing strategies to attract the maximum of clientele with the aim of making sure in the market and facing(dealing with) the competition.

\section{The composition of the Algerian banking system:}

To understand better the Algerian banking system, it is necessary to see the various stages by which the system passed since the independence has our days.

1.1. The creation of the institute of emission and the recovery of the monetary sovereignty. In the independence the Algerian state intends to recover all the attributes of the sovereignty, in particular the monetary sovereignty $^{5}$. The declaration of principle relative to the economic and financial cooperation of the Evian agreements of 19 Mars 1962, plans that particular agreements would have passed, between France and Algeria, as specifying the modalities of transfer of the privilege of emission. A protocol crossed between the Algerian State and the bank of Algeria confirms in the latter this privilege for a period of two months, as from July 1st, 1962. It was admitted, however, that this privilege of emission, exercised in passing title by the Bank of Algeria, could be extended however, it does not mean that this continuation goes beyond December 31st, 1962. In fact, this extension was used, by the Algerian authorities, to gather the material conditions and form the first frames which will be in charge of setting up the institute of emission, of independent Algeria.

So, from the day after the independence, Algeria gets back its monetary sovereignty and its "kingly right to emit of the currency", by creating his own institute of emission ${ }^{6}$. The last, called "Central Bank of Algeria" creates December 13th, 1962 and succeeds, from January 2nd, 1963, the bank of Algeria ${ }^{7}$.

2.1. The implementation of the national banking system. After the independence and to face the national reconstruction, Algeria created the $\mathbf{C A D}^{8}$. The latter is for purpose, to replace the French body.

\footnotetext{
${ }^{1}$ Officiel site web of the Central Bank of Algéria.

${ }^{2}$ Djamel BEN BELKACEM, central director of bank of Algéria, article published in the web site : manifest.univ-ouargla.com

3 Jean-Marc LEHU "Loyalty Strategy", Organization Edition, Paris 2003, page 181.

${ }^{4}$ Sylvie DE COURSSERGUES "Banking Management, From Diagnostics to Strategy" 5th edition, page 243.

${ }^{5}$ Abdelkrim NAAS "The Algerian banking system, from decolonization to independence", MAISONNEUVE \& LAROSE edition, Paris 2003 , page 11.

${ }^{6}$ The issuing institution is created by the law ${ }^{\circ} 62.144$ of December 13th, 1962 creating and fixing the statutes of the Central Bank of Algeria. The Decree of

December 28, 1962 fixes January 1, 1963 as the effective date of the BCA.

${ }^{7}$ The bank of Algeria was created by the law of August 4, 1851 and exercised the privilege of issue until June 30, 1962.

${ }^{8}$ The Algerian Development Fund, created by the law n ${ }^{\circ} 63-165$ of May 7th, 1963.
} 
Continuation has this creation and in 1964, the $\mathbf{C N E P}^{1}$ was created with the aim of collecting the individual savings to create and build housing. Followed by the BNA ${ }^{2}$, in 1966, which represents a deposit bank regarding collections of resources and regarding operations, she handles all the foreign-exchange transactions outside and various credit transactions. Later and in the same year, the implementation of the $\mathbf{C P A} \mathbf{A}^{3}$ to promote and support the tertiary sector with all its activities. Afterward, in 1967 a new named bank BEA ${ }^{4}$ is based to replace the following foreign establishments: the credit Lyonnais, the Société Générale, Of Barclay Bank Limited, the Credit of the North and the Industrial Bank of Algeria and the Mediterranean Sea. This bank has for main mission, facilitation and development of the economic reports of Algeria with the other countries within the framework of the financial planning 5 .

For a more precise specialization and after the organic restructuring of public enterprises; two banks were created: BADR ${ }^{6}$, from the structures of the BNA in 1982 and the $\mathbf{B D L}^{7}$ in 1985, from the structures of the CPA. The BDL is loaded of the financing of the local economic units under the supervision of wilayas and of municipalities. The characteristics of BADR are identical to those of the BDL, from the point of view of the supervision, from the point of view of the organization and from the point of view of the functioning.

1.3. The setting-up of the foreign banks in the Algerian banking system. Considering the importance and the stakes in the foreign banking investment in certain emerging countries and in transition, Algeria fast found itself forced to open his banking market to the foreign banks; and one of the main decisions of the law 90-10 of 14/04/1990 relative to the currency and to the credit is the opening of the banking system on the national private sector and the foreigner. Algeria is also a part of countries which have purpose to modernize their national banking sector and to benefit from experiences of the foreign partners in the banking sector. Besides, it followed an approach which establishes a mechanism allowing the already operational banks to open their capital to the foreign partners, within the framework of a transition of economy, taking into account the national interest such as creative project of jobs, or those being translated by a report of technology transfer or to know how to make. For that reason, Algeria gave the opportunity to other banks foreigner to establish on the market local financier; this setting-up was authorized after modifications in the institutional shape of the Algerian financial system, inferred by the commercial and financial opening of the latter, formalized by the banking prescription $n^{\circ} 01-01$ of February 27th, 2001 modifying and completing the banking law $n^{\circ} 90-10$ of April 14th, 1990 relative to the currency and to the credit. Continuation has these laws and always within the framework of the opening of the Algerian financial market and the encouragement of the IDE; a statutory text fixed the conditions of transfer of capital in Algeria to finance economic activities and repatriation of the latter and their income and dedicate, by the same, the opening of the state economy.

Table 1. Several foreign banks settled down in Algeria

\begin{tabular}{|c|c|c|}
\hline Foreign Bank & Date of application & Head office \\
\hline Bank Al Baraka Algeria & $20 / 05 / 1991$ & Bahrain \\
\hline Arab Banking Corporation Algeria (ABC) & 1998 & France \\
\hline Natixis Algeria & 1999 & France \\
\hline Société Générale Algeria (SGA) & 2000 & USA \\
\hline Citi Bank Algeria & 2001 & Jordan \\
\hline Arab Bank PLC Algeria & 2002 & France \\
\hline B.N.P / Paribas Algeria & 2002 & Ghana \\
\hline Trust Bank Algeria & 2003 & Jordan \\
\hline Housing Bank for Trade and Finance & 2003 & Abu Dhabi UAE \\
\hline Algeria Gulf Bank (AGB) & 2004 & France \\
\hline Fransabank Algeria & 2006 & France \\
\hline Calyon-Algeria & 2007 & Bahrain \\
\hline Al Salam Bank Algeria & 2008 & Hong Kong \\
\hline
\end{tabular}

Sources: the personal effort according to the official sites of banks.

The National Savings and Provident Fund, created by the law n ${ }^{\circ}$ 64-227 of August 17, 1964

${ }^{2}$ The National Bank of Algeria, created by the law $n{ }^{\circ} 66-178$ of June 13th, 1966.

The Algerian Credit Popular, created by the law n ${ }^{\circ}$ 66-366 of December 29th, 1966.

${ }^{4}$ The Foreign Bank of Algeria, created by the law ${ }^{\circ}$ 67-204 of October 1st, 1967.

${ }^{5}$ Abdelkrim NAAS "the Algerian banking system", edition Maisonneuve \& Larose, Paris 2003.

${ }^{6}$ Bank of Agriculture and Rural Development, created by the law n ${ }^{\circ} 82-106$ of March 13, 1982.

7 Local Development Bank, created by the law $n{ }^{\circ} 85-85$ of April 30th, 1985. 
1.4. The structure of the Algerian banking system at the hour current. According to the central bank, the structure of the banking sector A at the end of 2014, the banking system consists of twenty (20) banks among whom six (6) public banks and fourteen (14) private, filial banks or branches of big international banks. It includes also nine (9) financial institutions among which six public. The global indicators show that the level of the banking intermediation improves gradually under the angle of the development of the network, the number of the accounts, the level of the collected deposits and the distributed credits, although it stays below levels affected by certain nearby Mediterranean countries. The rhythm of setting-up of agencies of the private banks accelerates these last year's contributing to the development of the competition, as well at the level of the collection of the resources as at the level of the distribution of credits and the range of banking basic services to the clientele.

\section{The contribution of banks in the Algerian economy.}

The activity of banks in terms of collection of the resources and the distribution of credit progresses regularly, while the distribution activity of credits of financial institutions remains very low. An important part of the credits granted by the latter are it in conformance for the operations of leasing ( $85.9 \%$ against $78 \%$ in 2013), while they are not authorized to collect the deposits and to manage means of payment. Year 2014 registered a sharp increase in the active persons of banks (16.5\% against $6.8 \%$ in 2013), while the active persons of financial institutions are more moderated on the increase ( $7.4 \%$ against $9.2 \%$ in 2013 ) and represent only 0.6 $\%$ of the total of the assets of the banking sector. In the total of the assets of banks, the public banks remain dominant with a relative part of $86.8 \%$ at the end of 2014 against $13.2 \%$ for the private banks ${ }^{1}$.

\section{The inscription of Banks in the market exchange.}

According to the balance sheet(assessment) 2016 of the COSOB $^{2}$, the Algerian financial market counts at present nine (09) IOB $^{3}$ approved by the COSOB, it is about six (06) public institutions (BADR, BEA, BDL, BNA, CPA and CNEP) and three (03) institution deprived (Parisbas El Djazair BNP, Algeria Société Générale and Tell Markets spa).

Table 2. Algerian inscription of banks in the market exchange according to the COSOB

\begin{tabular}{|c|c|c|}
\hline Institution & Structure TCC & Structure IOB \\
\hline BADR & 02 & 01 \\
\hline BEA & 02 & 03 \\
\hline BNA & 02 & 02 \\
\hline BDL & 01 & 01 \\
\hline CPA & 01 & 02 \\
\hline CNEP Bank & 04 & 03 \\
\hline BNP Parisbas El Djazair & 02 & 03 \\
\hline Société Nationale Algéria & 00 & 01 \\
\hline Tell Markets & 00 & 02 \\
\hline Total & 14 & 18 \\
\hline
\end{tabular}

It is true that the contribution of banks in the stock exchange is very low, but we always notice that there is a lower contribution of the multinational banks by report of the national banks who dominate and chair the classification.

\section{The empirical study:}

4.1 Presentation of the empirical study. Our empirical study was based on a poll made on the clear by means of Google. Three hundred people participated in this poll. Then banks repeated in the answers are six public banks and six private banks. In everything, that makes twelve banks. The questionnaire counted came two questions, is in multiple choices or in open answers, the used tool it is the scale of Likert and the analysis was made by the software XL Stat. We chose in this article the questions which turnsall around the choice of the customer of banks.

\footnotetext{
1 Report of 2014.

${ }^{2}$ The COSOB: Commission of Organization and Surveillance of Stock Market Operations, a financial market regulator.

3 OIB: Accreditation of Intermediaries in Stock Market Operations.

${ }^{4}$ TCC : Qualification of Account Holders.
} 
4.2. Presentation of the graphs. The first graph demonstrates the distribution of the customers (client) in banks (public and private), we notice that the public bank is favored by the Algerian customer.

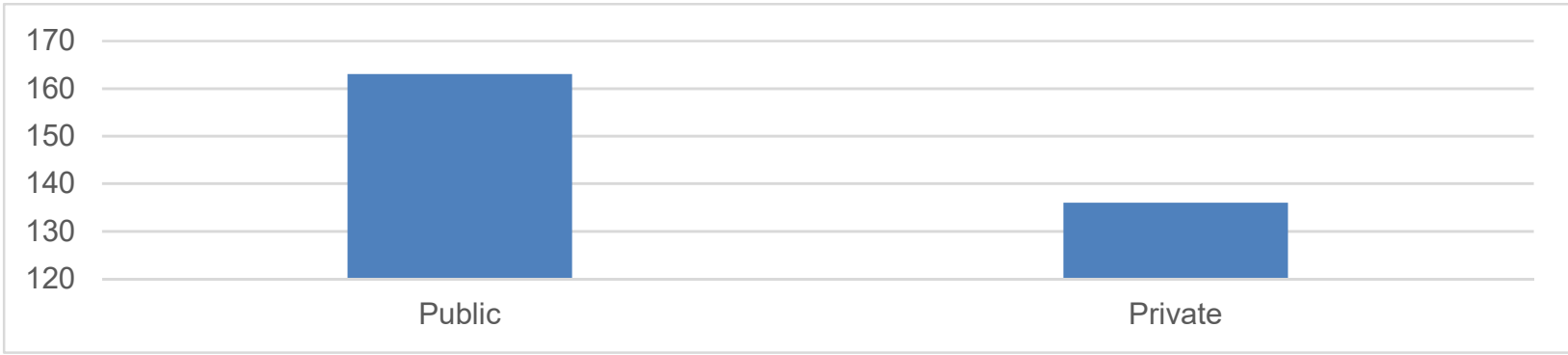

Figure 1. Distribution of the sample: public banks/private banks

In the second graph, we notice that the choice of the public bank is based on the good reputation of the bank, followed by the information circulated between the close friends (family and thus friends) it is a choice based on the culture of the society.

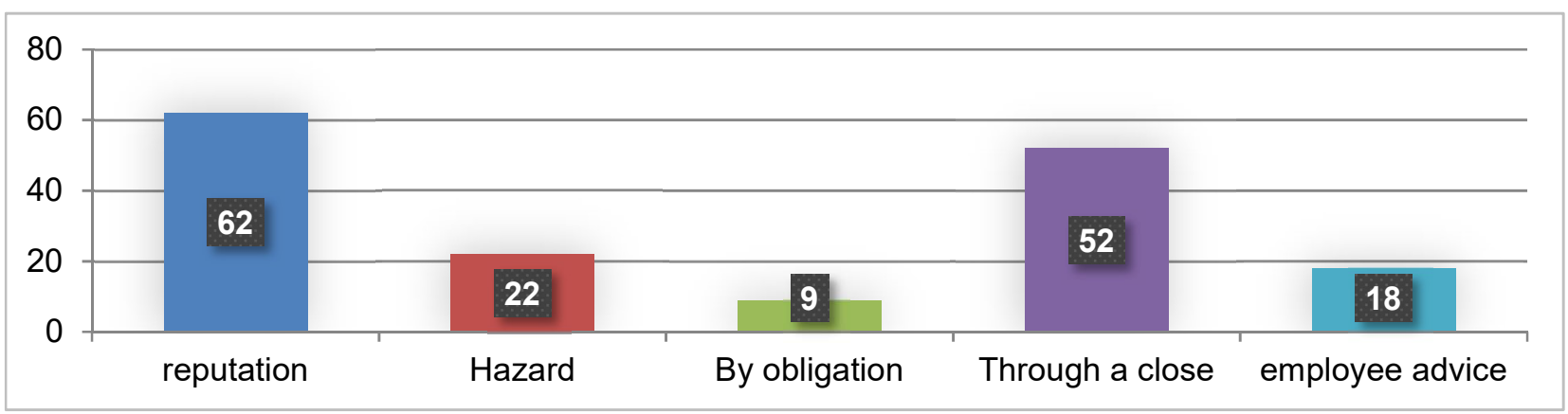

Figure 2. The choice of the public bank

The third graph represents the loyalty of the customers in the public banks, in remark which $64 \%$ of the clients assert that they plan to remain clients in the public bank.

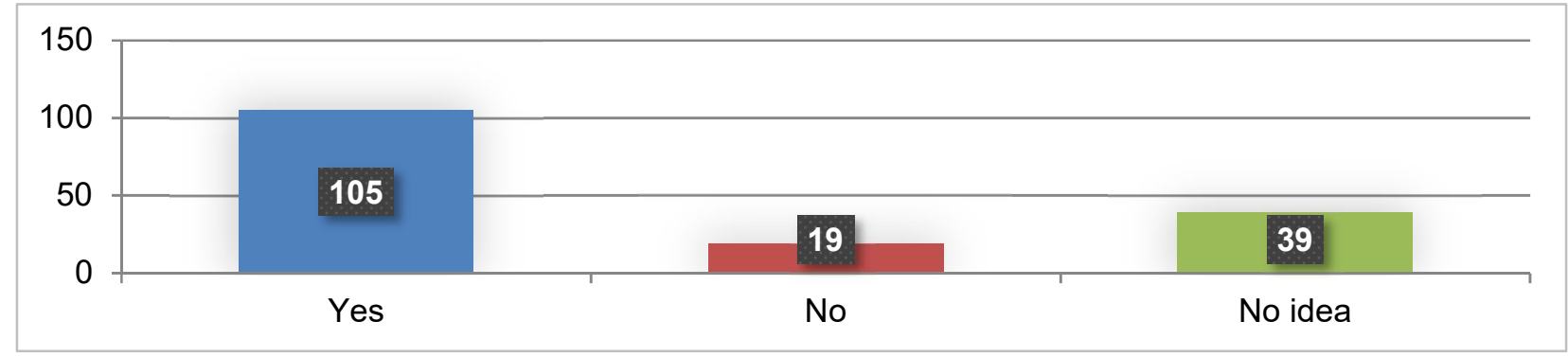

Figure 3. The loyalty of the customers in the public banks

The fourth and the last graph shows us the reason why the Algerian client remains faithful for the public bank, we notice that the majority of the clients remain faithful for safety reasons.

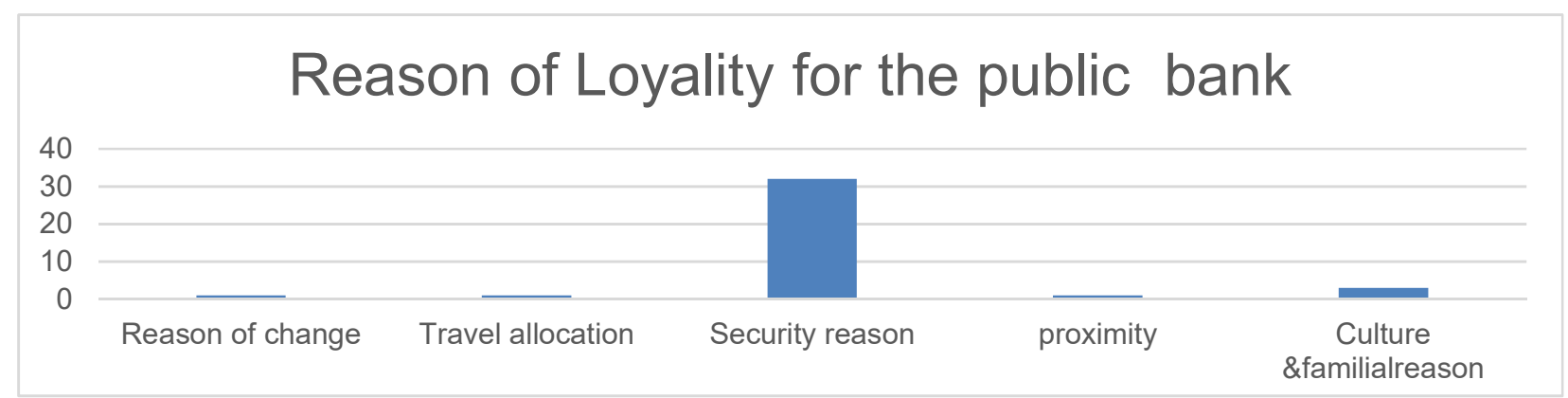

Figure 4. The reason of loyalty for the public bank

Thus, in spite of the opening of the Algerian market and the setting-up of fourteen foreign banks who represent more than doubles him public banks, and in spite of the integration of new technologies by the foreign banks. 
The Algerian customer prefers mainly the public bank. A relationship of trust and safety between the client and his bank, even if the foreign bank is more developed, it does not explain according to our search results that the latter is favored.

\section{Conclusion}

In spite of the double number of the foreign banks with compared with the national banks. So in terms of comparative approach of the data generated by the Bank of Algeria and the COSOB, we notice the domination of the National banks in the banking activity. However, it is necessary to note that the Algerian national large companies are domiciled in six national banks, giving the example of the SONATRCH which is domiciled in BEA, also the CPA which takes care of all the hotels of the chain " STRAWOOD" dominated by the law 49/51, which gives in Algeria the decision-making power by its part of $51 \%$, this law is quoted in the article 83 of the prescription $\mathrm{N}^{\circ} 03-11$ of August 26th relative to the credit and to the change. We also note that the big national public investments in their towers are managed by the national banks. Also, the private individuals are obliged rather of the operations in the national banks, especially than the social credits are also entrusted to the latter. Then, that the foreign banks just take care IDE, and other bank transactions which exist in the other national banks mentioned by conditions fixed in the article 91 of the prescription $\mathrm{N}^{\circ} 03-11$ of August 26th, 2003 relative to the change and to the credit.

This is why our banks are not rather up to date and to the world technology, in spite of the foreign banks in their country of origin apply new standards, giving the example of the Société Générale France which has a whole department for the RSE, also NATIXIS forks out who gives of the importance to the sustainable development and the recycling of products.

It is necessary to say also that the Algerian banking system limited itself in the financial domain and the credit generally speaking, except that recently it begins to give the importance for the marketing, because the customer becomes awake and require day after day, especially that the foreign banks integrate a well chosen staff and give of the importance to the relation customer-bank. This transition is marked in the prescription $\mathrm{N}^{\circ} 03-$ 11 of August 26th, 2003 relative to the change and to the credit, by the article 91 which insists on the good progress of the banking system which must be assured by the quality of the customers departments, so in the article 96 which has for object the introduction of new technologies, the organization, the management of the departments and the application of the marketing.

However, the Algerian customer with a specific character mainly influenced by the traditions, the customs and the religion, this is why banks begin to throw products says "Hallal", or the alternative finance to attract the maximum of clientele.

At the end, we are going to say that our Algerian banking system is improving by changing every time the laws and by modifying the prescriptions by applying new visions and modern technologies.

\section{References}

1. Ammour. B. (2001). The Algerian Banking System, Dehleb Edition, Algiers.

2. Ansoff Igor. (1993). Matrix, Environment and Growth-an Interactive Triangle.

3. Badoc, M. (2007). In Collaboration With Trouillaud. E. The Basics of Banking Marketing and Insurance, Revue Banque, Paris.

4. Brechignac-Roubaud. B. (1998). Preface of Brousse. Marketing Services, from The Project to the Marketing Plan, Edition of Organization, Paris.

5. Knight, M And Fenwick, R. (1975).The Marketing Strategy Edition La Presse Universitaire De France, 1 st Edition, Paris.

6. Coussergues, S. (2007). Bank Management, Dunod Edition, 2nd Edition Enriched And Updated And 5th Edition, Paris.

7. Desmicht, F. (2007). Practical Banking Dunod Edition, 2nd Edition, Paris.

8. Emery And Trist. (1963). The Causal Texture Of Oraganizattinal Environment, Washington Dc, Usa, Agust.

9. Drucker Peter. (1992). The Age Of Discontinuity: Guidelines To Our Changing Society, Copyrighted Material Edition, New York.

10. Giannelloni, J. and Vernette, E. (2001). Market Study" Vuibert Edition, 2nd Edition, Paris.

11. Hassam, F. (2005).The Algerian Banking System" Edition 2 Economist Of Algeria, Algiers.

12. Lamarque.E. (2014). Preface By Pauget, G. Banking And Insurance Strategy, Dunod Edition, Paris. 
13. Lovelock, C. and Lapert D. (1999). Marketing Services. Strategy. Tools. Management, Public Union Edition, Paris.

14. Naas, A. (2003). The Algerian Banking System, Maisonneuve \& Larose Edition, Paris

15. Plihon. D, Cuppey-Soubeyran. J And Saidane. D. (2006). Banks Involved in Financial Globalization" Edition La Documentation Française, Paris.

16. Zollinger. M And Lamarque.E. (2017). Marketing And Strategy of The Bank" Edition Dunod, Paris.

17. Benbelkacem. D, Central Director of The Bank of Algeria, Recent Reforms of the Banking System, Manifest Univ Ouaregula.

18. National Symposium Of March 4, 2015 In The Framework Of The Research Laboratory "The International Regime Of Some Banking Operations" Review Of Banking Law And International Finance, Oran University 2, Review $\mathrm{N}^{\circ} 7$ March 2015.

19. Laurent Bombar. (2010). Phd Thesis In Management Sciences Of The Cnam, Laboratory Of Investigation And Prospective Strategy And Organization Lipsor.

20. Mohamed Cherchem. (2011). Knowledge And Innovation In Services As A Factor Of Competitiveness, Case Of Algerian Banks And Public Insurance" Communication Published In The Framework Of The Conference On Knowledge Capital.

21. Nadjib Anis Benahmed. Algerian Public Banks: For A Global Marketing, Revue Des Sciences Commerciales, 9(18), 77-95.

22. Nedjma Bernoussi. (2010). Marketing Segmentation, From Market Research to Marketing Strategy, University Publications Office, Algiers.

23. Troudart, J. (2012). Analysis And Comparison Of Internationalization Strategies Of Banks Phd Thesis In Management Sciences, Montesquieu University, Bordeaux Iv, December.

24. Executive Decree No. 10-199 Of 20 Ramadhan 1431 Corresponding To August 30, 2010 Setting The Rules For Overflight Of Algerian Territory By Foreign State Aircraft.

25. Ordinance No. 90-10 Of 14 April 1990 On Money And Credit. 